\title{
CHOCOLATE-ON-WHITE WARE: FURTHER OBSERVATIONS AND RADIOCARBON DATES
}

By Peter M. Fischer

\section{INTRODUCTION}

Since the study on the typology, chronology and provenance of Chocolate-on-White Wares from the settlement of Tell Abu al-Kharaz, Jordan Valley was published (FISCHER 1999), the author has had the opportunity to investigate related wares from Pella's Tomb 62 visually at first hand. The studied vessels, which are a part of the assemblage from Tomb 62 and the majority of which were virtually or completely intact, are stored in the Pella Room and in the Nicholson Museum, both at the University of Sydney, Australia. ${ }^{1}$

One of the aims of this study is to try to classify the Chocolate-on-White material from Pella Tomb 62 which is stored in Sydney, according to the criteria which were established by the author. These criteria are based on the Chocolate-on-White material from the settlement of Tell Abu al-Kharaz, which lies approximately $6 \mathrm{~km}$ to the south of Pella in the Jordan Valley (Fig. 1). The Chocolate-on-White material from Pella's Tomb 62 provides the opportunity to study complete vessel shapes in contrast to the material from Tell Abu al-Kharaz, which only produced a limited number of complete vessels.

Another goal is to try to clarify whether the provisional stratigraphy of the tomb and the associated vessels are in agreement with the diachronic pattern of the Chocolate-on-White Ware from the settlement of Tell Abu al-Kharaz thus suggesting a better defined time span for the tomb.

The final aim of this study is to date the Tell Abu al-Kharaz Chocolate-on-White Ware and its contexts and as a consequence the classified Pella material according to the absolute dates which are provided by the VERA-Laboratory in Vienna (five dates) and the AMS-Laboratory in Oxford (two dates).

\section{Problems of Classification-Criteria}

In his previous study of Chocolate-on-White, this author has highlighted the problem of various possible interpretations when published material is studied visually at second hand (cf. FIsCHER 1999: 2-3). Vessels studied at second hand could, for example:

1. represent Chocolate-on-White satisfying a prestated range of criteria (see the author's definition below).

2. represent a bichrome variant of Chocolate-onWhite, which differs from the locally produced or imported burnished or unburnished bichrome-decorated wares of the Middle and Late Bronze Ages.

3. be a harbinger of Chocolate-on-White from the Middle Bronze Age.

4. be monochrome- or bichrome-decorated vessels from the later part of the Middle Bronze Age and the first part of Late Bronze Age, whose shapes and/or decorations correspond to Chocolate-on-

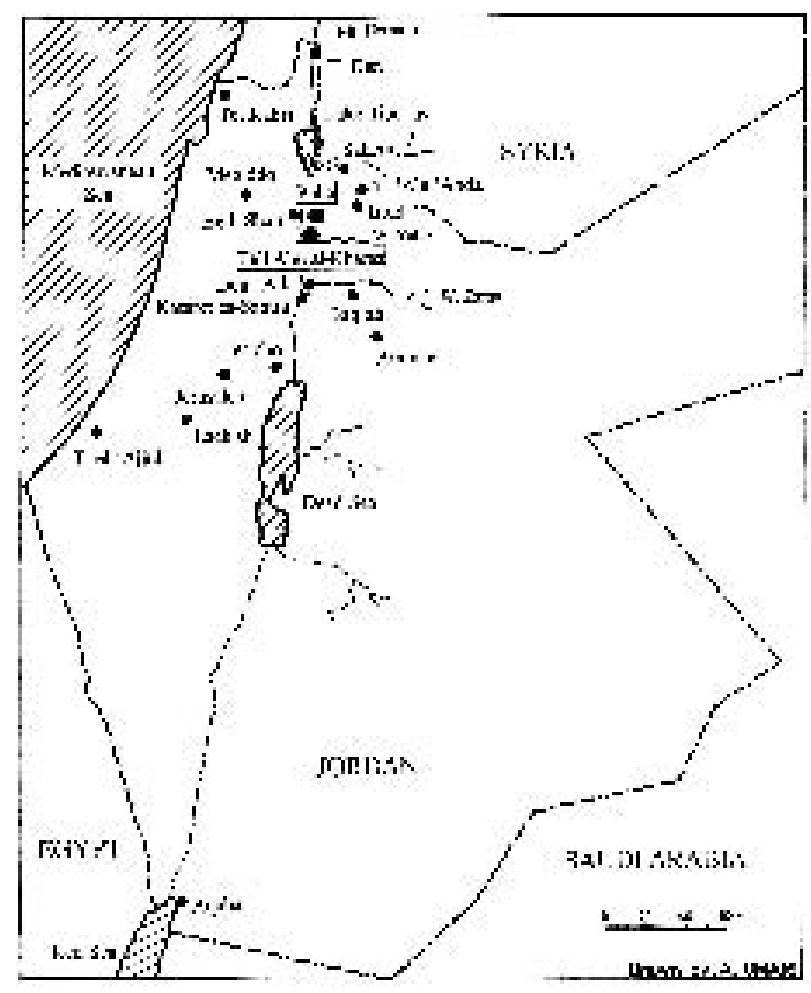

Fig. 1 The position of Tell Abu al-Kharaz and Pella. All sites on this map except for Sahem (tomb) and Aqaba have finds of Chocolate-on-White

\footnotetext{
1 The remaining assemblage is stored at the Department of Antiquities of Irbid.
} 
White, but which lack some of the ware's most crucial criteria, e.g. have just a self-slip or merely a thin bright slip or wash and no applied burnish.

Only representatives of Groups 1-3, which fulfil the following necessary criteria, should therefore be included within the Chocolate-on-White Ware group: $:^{2}$

- the vessels are as a rule wheel-made

- relatively thick slip covers the entire surface (open shapes)

- or extends to the point where it can be reached by the potter's brush (closed shapes)

- the slip is most often "white", although it may range from pink through yellowish-white to light grey (see below)

- the slip is burnished on a wheel, or at least a turntable; early examples may be hand-burnished, usually vertically

- the vessels are in general decorated (all shapes) but there are exceptions of groups of vessels which are plain-burnished:

1. Eggshell Ware (ES) which includes carinated bowls and small jars of a thin and fine ware

2. a few large kraters, which in shape resemble the contemporary cooking-pots but also show some traits of the biconical jars ${ }^{3}$

3. a few jugs and juglets ${ }^{4}$

- the decoration is always matt and applied on the burnished slip

- closed vessels in general show decoration (exceptions see above), which is most often confined to the upper part of the vessel

- the decoration of open vessels is applied on the exterior only, ${ }^{5}$ the interior only ${ }^{6}$ or quite often on both sides ${ }^{7}$

- the decoration is frequently dark reddish-brown (chocolate-brown), but it covers a colour spectrum from light red to "black" (very dark brown)

- vessels may be bichrome-decorated, most frequently "red" and "black"

- the "perfect" finish alone is not taken as a criteri-

2 These criteria which are based on the material from Tell Abu al-Kharaz have been completed after the investigation of the Pella material (cf. Fischer 1999: 4)

3 This type occurs at Tell Abu al-Kharaz.

4 These belong to the Pella Tomb 62 material.

${ }^{5}$ An example where the decoration is only on the exterior is a carinated bowl from Pella Tomb 105 (BOURKE 1994: 111, fig. 18: 6, and 116).

${ }^{6}$ Examples, where the decoration is only on the interior on (contra Amiran 1970: 158-159; see also HeNNESSY 1985: 112); ${ }^{8}$ however, the majority of the vessels are carefully wheel-finished and, when decorated, most often excellently executed except for representatives from the end of the life span of the Chocolate-on-White Ware

- the clay is usually hard-fired in oxidizing and/or reducing conditions; the fired clay's hardness ranges between 4-6, the majority around 4-5, according to Mohs' index (1-10), i.e. the surface can be scratched by window glass (around 4.5) or stainless steel (around 6)

- the inclusions vary considerably from very fine to very coarse (WENTWORTH 1922: 377-392; 1933: 633-634).

Six sub-groups were recognized in the Chocolateon-White material from the settlement of Tell Abu al-Kharaz: Proto-Chocolate-on-White (Fig. 2:1), Chocolate-on-White Bichrome (Fig. 2:2), Eggshell Ware (Fig. 3:4), Chocolate-on-White I (Fig. 3:1-3, Chocolate-on-White II (Fig. 4:1-2, 5:1) and Chocolate-on-White III (Fig. 5:2). ${ }^{9}$

\section{Pella Tomb 62 And its contents}

A number of rich tombs were found on the north-east ridge of Tell el-Husn, among which Tomb 62 is the richest (Роттs 1985: 206-210; 1992: 69-81). It consists of three rock-cut chambers which were entered through a short dromos. A step leads from Chamber 1 up to Chamber 2, from which Chamber 3 can be entered. The roofs of Chambers 1 and 2 had completely and that of Chamber 3 partially collapsed crushing much of the contents. The total inventory of approximately two thousand objects makes Tomb 62 one of the largest and richest tombs in the Levant.

\section{Chocolate-on-White IN Sydney}

All available vessels from Tomb 62, the majority of which are stored in the Pella House and some vessels in the Nicholson Museum, were studied. The Eggshell Ware, the total of which is 160 bowls (KNAPP 1993: 35, here called "Burnished White Slip"; not all of them are in Sydney), was quite uni-

come from, for example, Tell Abu al-Kharaz (Fischer 1999: 10, fig. 5: 1-2).

7 E.g. Tell Abu al-Kharaz (Fischer 1999: 9, fig. 4).

8 The surface treatment is in general superior to the quality of the clay.

9 Chocolate-on-White III represents a transitional type, which is difficult to distinguish from common decorated ware. 
form in shape and production technique. In contrast, the jugs and bowls, in particular, of the Chocolate-on-White Ware show obvious differences as regards vessel shape and decoration. The following vessels were classified as representatives or forerunners of the Chocolate-on-White Ware: 29 jugs, three cylindrical juglets and five bowls (Table 1, Figs. 6-9).

The jugs were separated into six main types, Types I to VI (Figs. 6-8), with subdivisions according to the number of handles, 0,1 or 2 (none, one or two handles):

Type I1 (Fig. 6:1, 2): high shoulder, one handle on shoulder, monochrome- or bichrome-decorated Type III: as Type I, no decoration

Type III1/2 (Fig. 7:1, 2): low shoulder, one or two handles, monochrome-decorated

Type IVO/2 (Fig. 8:1, 2): biconical with marked shoulder, no handle or two handles on shoulder; hybrid of "common" jug and biconical jug, monochrome-decorated

Type V1: roughly biconical, one handle on shoulder, monochrome-decorated

Type VI: globular/piriform profile, one handle from rim to belly, bichrome-decorated

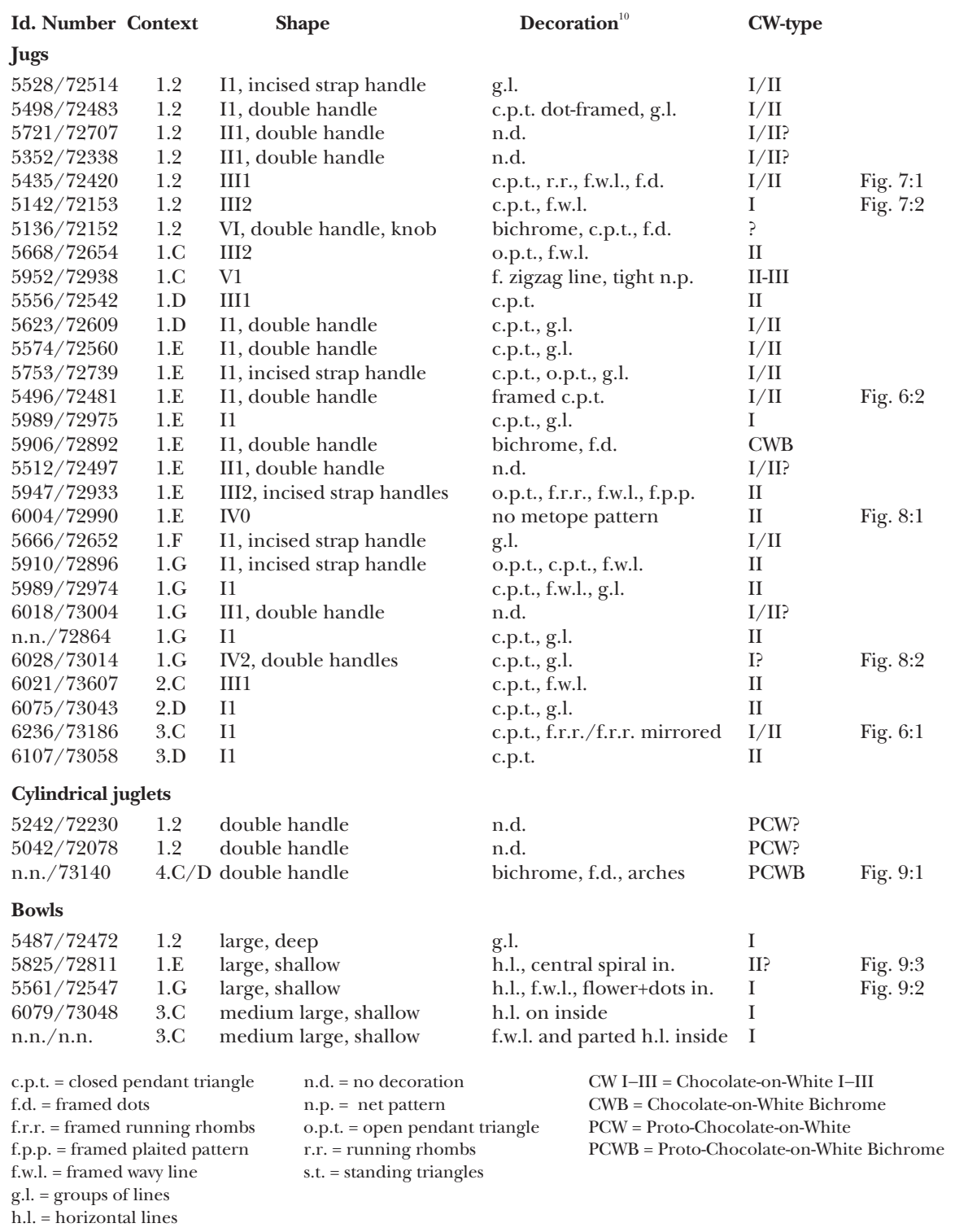

Table 1 Chocolate-on-White Wares without representatives of Eggshell Ware from Tomb 62 in Sydney sorted according to chambers and "stratigraphy"

${ }^{10}$ Metope pattern if not otherwise stated. 


\begin{tabular}{|c|c|c|c|}
\hline & Tell Abu al-Kharaz & & Pella Tomb 62 \\
\hline & Special features & Common features & Special features \\
\hline Ware & $\begin{array}{l}\text { PCWB jug } \\
\text { CWI-III, ES }\end{array}$ & $\begin{array}{l}\text { PCWB, CWB, } \\
\text { Type VI }\end{array}$ & PCWB cylindrical juglet \\
\hline Shapes & $\begin{array}{l}\text { jug handles on belly } \\
\text { jug handles from upper neck } \\
\text { jug neck ridge } \\
\text { undecorated kraters }\end{array}$ & ring bases & $\begin{array}{l}\text { Types II1, IV0, IV1 } \\
\text { high shoulders } \\
\text { double handles more common } \\
\text { undecorated jugs/juglets }\end{array}$ \\
\hline Decoration & $\begin{array}{l}\text { shooting stars on handles } \\
\text { faunal motifs } \\
\text { stylized trees } \\
\text { checker pattern } \\
\text { ladder pattern }\end{array}$ & $\begin{array}{l}\text { rare bichrome dec. } \\
\text { pendant triangles } \\
\text { framed dots } \\
\text { framed wavy lines } \\
\text { framed running rhombs }\end{array}$ & $\begin{array}{l}\text { flower motif } \\
\text { framed plaited pattern } \\
\text { net pattern }\end{array}$ \\
\hline
\end{tabular}

Table 2 Uniformity and diversity of the Tell Abu al-Kharaz and Pella Chocolate-on-White Ware vessels concerning shapes and decoration

\section{Results AND Discussion}

\section{Classification}

PotTs (1992: 69-81) reports a total of 1,215 ceramic vessels from Tomb 62 in Area XI at Pella. Ninety-five vessels were classified as representatives of Chocolate-on-White Ware. It is the author's opinion that not all of them really satisfy the Chocolate-on-White Ware criteria. PotTs (1985: 206-210, fig. 9: 3, 4 and fig. 10: 3) described, for example, in the first report on Tomb 62 three vessels as representatives of Chocolate-on-White Ware which in my view rather belong to Group 4 (see above "II. Problems of Classification-Criteria"). There are also additional monochrome-decorated examples (Роттs 1992: 69-81; e.g. pls. 53:5; 55:1-3; 57:3) and a bichrome decorated jug with a self slip from Tomb 60 (PO 75/30099 in McNicoll, SMITH and HenNESSY 1982: pl. 112: 6) whose assignation to the Chocolate-on-White Ware group can be questioned. The opposite situation is represented by the 160 carinated thin-walled bowls with a thick white slip and a wheel-burnish (some examples in PotTs 1992: pl. 54, 1-4). These are certainly representatives of the Chocolate-on-White group of Eggshell ware, some of them actually being decorated (arguments in Fischer 1999: 11-12; see also PotTs 1992: pl. 54, 3 with a chocolate-coloured

11 The pendant triangle is most likely an abstraction of the tree-motif.

12 There are additional vessels of the transitional type cross painted on the base although not on the drawing), which has been confirmed during my visit in Sydney where a representative study collection of this vessel type is stored.

The present discussion of the Pella Tomb 62 material is mainly based on examination of the material from the nearby settlement of Tell Abu alKharaz, the stratigraphy of which provided the basis for the classification of the Chocolate-on-White group of wares. Six groups, which include a forerunner of the "developed" Chocolate-on-White Ware (Proto-Chocolate-on-White Bichrome; FISCHER 1999: 7, fig. 3: 1) and a type which is difficult to distinguish from common decorated ware (Chocolateon-White III; idem: 17, fig. 12: 3), ${ }^{12}$ were recognized: Proto-Chocolate-on-White Bichrome, Chocolate-onWhite Bichrome, Eggshell Ware and Chocolate-onWhite I-III (representatives in Figs. 2-5). Further studies of the Chocolate-on-White Ware have shown that transitional types exist, especially as far as Chocolate-on-White I and II is concerned. One example is a Chocolate-on-White jug from Tell Abu al-Kharaz which is classified as Chocolate-onWhite II and whose decorative elements and finish may well fit within the Chocolate-on-White I repertoire but which was found in the same context as clearly identified Chocolate-on-White II vessels (idem: 16, fig. 11: 2). This observation may to a cer-
Chocolate-on-White III/common ware in the Pella material which are not listed in Table 1. 
tain extent explain why a great number of Chocolate-on-White Ware vessels from Tomb 62, where the stratigraphy is blurred or non-existing, are classified as Chocolate-on-White I/II.

\section{Production}

A general although more empirical than unarguable observation, when the material from the two sites is compared, is the relative diversity of the Tell Abu al-Kharaz material and the comparative uniformity of the Pella material (Tables 1 and 2). It seems that the Tell Abu al-Kharaz material comes from different workshops (see petrography below) and that the Pella material points more to a limited area or even a centre of production with only a few potters participating in the manufacture of this ware, at least concerning the bulk of the Pella material. In any case, the majority of the Chocolate-on-White Ware vessels which derive from the Pella Tomb 62 are carefully manufactured and show an excellent finish which is the result of a time-consuming process. This confirms the observation that Chocolate-on-White Ware, Chocolate-on-White III excluded, is an outstanding product of a highly developed ceramic industry. It was together with other decorated table wares such as imported Cypriote Bichrome and Cypriote White Slip certainly the most exclusive painted ware on the Levantine mar$\mathrm{ket}^{13}$ towards the end of the Middle Bronze Age and at the beginning of the Late Bronze Age (FISCHER 2000b). The author cannot therefore agree with the statement that it is the quantity rather than the quality of the contents of Tomb 62 that is unusual and that no finds suggest occupants of great wealth or status (PотTs 1992: 70-71). ${ }^{14}$

Petrography of the Tell Abu al-Kharaz material has shown that Lower Cretaceous clay, together with siltstone, ferruginous ooliths and variegated shale fragments, is the main constituent in ProtoChocolate-on-White Bichrome and in Chocolate-on-White $I$ (northern type). ${ }^{15}$ The main sources of Lower Cretaceous clay in the area are the surroundings of the Mt. Hermon massif in southern Lebanon. There are in addition very small exposures of this type of clay in eastern Samaria, some outcrops in the central Negev craters, and some exposures between Wadi al-Zerqa and Feinan. Chocolate-on-White I (southern type) shows a different clay which consists of marl with red rhombs together with calcareous, basalt and chert sand (Jordan sand), which points to a Central Jordan Valley provenance. Eggshell Ware is characterized by undifferentiated marl, quartz, chert, limestone, Nubian sandstone and calcareous formations, which may also point to a clay source from the Central Jordan Valley. Chocolate-on-White Bichrome, one type of Chocolate-on-White II and Chocolate-on-White III are characterized by Taqiya marl with calcareous, basalt and quartz/chert sand which is supposed to be a product of the Central Jordan Valley. Other raw materials were used in the second "type" of Chocolate-on-White II, namely undifferentiated marl, calcareous, sand and siltstone mixed with red (dolomite altered?) rhombs, which may come from a local clay source.

Petrography is a simple and cheap method which has been used for quite a considerable period (cf. GOREN and Fischer 1999; VAUGHAN 1999). Data banks with material from the Levant and other culturally related areas in the Eastern Mediterranean are increasing and valuable information about matching wares and the possible provenance of pottery can be attained. Petrography may also be combined with other methods and direct the selection of samples for further chemical methods such as neutron activation analysis. Therefore petrography, which is certainly the most suitable technique for exploring the relationship of the Chocolate-onWhite material from our two sites and subsequently applying the results on material to other sites with related finds, should be utilized.

\section{Dating}

Two contexts from the settlement of Tell Abu alKharaz, from which radiocarbon samples were taken, reflect some of the problems when organic material is collected for later radiocarbon analysis. One sample (VERA-1407; not in Table 3) was taken in order to date the earliest layer of reoccupation (Phase IV)

${ }^{13}$ Just a few finds of Chocolate-on-White are reported from Lebanon and Syria, and from Egypt none so far (see discussion and references in FiscHER 1999: 2).

$14 \mathrm{~S}$. BOURKe, who is one of the excavators of Tomb 62 , suggests that Chocolate-on-White is probably a good indicator of wealth of the "Middle Classes" (mer-

chants, farmers etc) rather than the rulers (pers. communication).

15 All information concerning petrography and mineralogy has been received from Y. GOREN who also carried out the petrographical analyses of the Tell Abu alKharaz material (see FISCHER 1999: 21). 
after an occupational lacuna which lasted for more than a thousand years after the final catastrophe within the Early Bronze Age II(/III?) which corresponds to Phase III (FIsCHER 2000a). The first sample derives from a locus which contains Chocolate-on-White I (FisCHer 1999: 9, fig. 4: 1; here Fig. 3:1). The locus represents a foundation layer which was dug by the people who resettled Tell Abu al-Kharaz at the end of the Middle Bronze Age. The radiocarbon date of this sample is $3340(95.4) 2930$ B.C. This date shows that the new settlers mixed material from their own period with the older Early Bronze Age material when they dug their foundation trenches. The sample dates clearly to the end of the Early Bronze Age occupation at Tell Abu al-Kharaz. It is highly valuable per se and in excellent agreement with earlier radiocarbon dates provided by the Oxford laboratory in connection with a large scale Early Bronze Age dating project (FisCHER 2000a: 222-229; especially 228, table 12.3, Tell Abu al-Kharaz Phase III). A similar problem is demonstrated by the radiocarbon date, which is provided by VERA-1409 (not in Table 3): 3340(95.4) 2920 B.C. This sample was taken from the foundation trench of a late Middle/Late Bronze Age defence system (Fischer 1998: 217, fig. 6). Consequently there are so far no radiocarbon dates of layers which contain Chocolate-on-White I, Proto-Chocolate-on-White and Chocolate-on-White Bichrome which should all be earlier ${ }^{16}$ than the radiocarbon dates discussed here (see Fischer 1999: 18, table $2^{17}$ ).

Eggshell Ware (ES) has been provisionally dated by the author to the later part of Phase IV at Tell Abu al-Kharaz, i.e. the end of the Middle Bronze Age, with a life span which - as it was suggested - may extend into Late Bronze Age IA ${ }^{18}$ (Phase V; FIsCHER 1999: 11-13, 18, 24). A representative locus with Eggshell Ware from Tell Abu al-Kharaz is now dated by VERA-1414 with $2 \sigma$ confidence and a $95.4 \%$ probability between 1520 B.C. and 1410 B.C. This date lends support to the hypothesis that the life span of Eggshell Ware extends into Late Bronze Age IA. This has also been confirmed by recent finds from Horizon 5 at Tell el-cAjjul (Fischer 2002).

Three samples derive from contexts with Chocolate-on-White II, these are VERA-1408, OxA-5089 and -5090. The fourth sample, VERA-1413, comes from a

\begin{tabular}{|c|c|c|c|c|c|c|}
\hline Lab. No. & $\begin{array}{l}\text { Material } \\
\text { Spot }\end{array}$ & $\begin{array}{l}\delta^{13} \mathrm{C} \\
{[\% o]}\end{array}$ & ${ }^{14} \mathrm{C}$-dates $[\mathrm{BP}]$ & \multicolumn{2}{|c|}{ Calibrated dates B.C. } & $\begin{array}{l}\text { Associated } \\
\text { CW }\end{array}$ \\
\hline VERA $^{21}-1408$ & $\begin{array}{l}\text { wood/seeds } \\
\text { floor }\end{array}$ & $-26.9 \pm 0.9$ & $3195 \pm 30$ & $1500(68.2) 1430$ & $1520(95.4) 1410$ & II \\
\hline VERA-1411 & $\begin{array}{l}\text { wood } \\
\text { floor }\end{array}$ & $-27.0 \pm 0.9$ & $3120 \pm 50$ & $\begin{array}{l}1490(01.5) 1480 \\
1450(66.7) 1310\end{array}$ & $1520(95.4) 1260$ & III \\
\hline VERA-1413 & $\begin{array}{l}\text { wood } \\
\text { floor }\end{array}$ & $-24.4 \pm 0.9$ & $3145 \pm 25$ & $\begin{array}{l}1440(65.3) 1390 \\
1330(02.9) 1320\end{array}$ & $\begin{array}{l}1500(08.3) 1470 \\
1460(79.1) 1370 \\
1340(08.0) 1310\end{array}$ & II? \\
\hline VERA-1414 & $\begin{array}{l}\text { Wood } \\
\text { floor }\end{array}$ & $-28.0 \pm 0.8$ & $3190 \pm 30$ & $1500(68.2) 1425$ & $1520(95.4) 1410$ & $\mathrm{ES}$ \\
\hline VERA-1415 & $\begin{array}{l}\text { wood } \\
\text { floor }\end{array}$ & $-25.6 \pm 0.9$ & $3195 \pm 30$ & $1500(68.2) 1430$ & $1520(95.4) 1410$ & III \\
\hline $\mathrm{OxA}^{22}-5089$ & $\begin{array}{c}\text { seeds } \\
\text { outside silo }\end{array}$ & $-23.2 \pm 0.5-1.0$ & $3260 \pm 50$ & $\begin{array}{l}1620(92.0) 1509 \\
1476(08,0) 1463\end{array}$ & $1672(100) 1441$ & II \\
\hline OxA-5090 & $\begin{array}{l}\text { seeds } \\
\text { inside silo }\end{array}$ & $-23.4 \pm 0.5-1.0$ & $3210 \pm 60$ & $\begin{array}{l}1588(10.0) 1571 \\
1527(90.0) 1424\end{array}$ & $1639(100) 1394$ & II \\
\hline
\end{tabular}

Table 3 Radiocarbon dates from Tell Abu al-Kharaz

16 The exception may be Chocolate-on-White Bichrome. A possible life span into Late Bronze Age IA is suggested (FISCHER 1999: 18, table 2).

17 Observe that "CW III in early part of Phase VI" is correct (and not as written: "Phase IV").

18 See the suggested chronological framework in FisCHER 1997: 20, Table 1; 1999: 18, table 2.

$191 \sigma(68.2 \%)$ age range.
$202 \sigma(95.4 \%)$ age range.

21 VERA refers to Vienna Environmental Research Accelerator, Institute for Radium Research and Nuclear Physics, University of Vienna.

${ }^{22}$ OxA refers to The Research Laboratory for Archaeology and the History of Art, Radiocarbon Accelerator Unit, Oxford University. 
context with possible Chocolate-on-White II. The $2 \sigma$ dates of OxA-5090, i.e. 1639(100) 1394 B.C., offer too a wide time range to be of any value for the discussion of a more precise date of Chocolate-on-White II. However, the $1 \sigma$ time range, 1527(90.0) 1427 B.C., is in good agreement with the relatively narrow $1 \sigma$ and $2 \sigma$ time range which are offered by VERA-1408: $1500(68.2) 1430$ B.C. and 1520(95.4)1410 B.C. respectively. These dates lend support to the suggested chronology of the Chocolate-on-White II (Fischer 1999: 18, table 2). The dates provided by OxA-5089 suggest a somewhat higher date for Chocolate-on-White II, but a Late Bronze Age IA date is still possible. The lowest dates are provided by VERA1413, the sample which comes from a context with possible Chocolate-on-White II, and would go well with Late Bronze Age IB. On the other hand, the $2 \sigma$ date is with a $8.3 \%$ probability in agreement with the other dates of Chocolate-on-White II contexts.

One sample was taken from a context with Chocolate-on-White III, VERA-1415. It is interesting to note that the date of this ware, which is difficult to distinguish from "common" decorated Late Bronze Age wares, does not differ from the dates suggested for Eggshell Ware and Chocolate-on-White II. There are a number of possible explanations, two of which are most likely: Chocolate-on-White III is an inferior, contemporaneous, product of a less experienced workshop/potter or the result of the waning standard of the Chocolate-on-White production.

It was not possible to observe any relation and consequently any diachronic pattern between the provisional "vertical stratigraphy" of Tomb $62^{23}$ and the different Chocolate-on-White Wares from the tomb, which were compared and dated in relation to the material from Tell Abu al-Kharaz and its relative and absolute dates. This observation may lend support to the statements of the excavators (PотTs 1992: 69):

"The tomb contents were stratified in irregular deposits of collapsed roof rock, bone fragments and silt up to nearly a metre deep; but these layers reflect the processes of final deposition, subsequent to the closure of the tomb, not a sequence of interments. Water had evidently washed or seeped into the tomb and then subsided leaving behind bands of fragmented bone and silt. Many of the vessels, especially the closed shapes, floated and settled amongst this debris. But some vessels project through a number of layers and others seem to be suspended between. It remains to be seen if any chronological significance can be given to this "stratification". Some deposits seem to have sealed the layers below them and if this process began while interments were still being made it may prove possible to provide reliable general categories of early, middle and late. But it is extremely doubtful that it will yield any sound basis for a chronological ceramic typology or estimates of relative frequencies of the forms represented. Preliminary analysis of the corpus has not revealed anything which obviously over-reaches the limits of Middle Bronze IIC and Late Bronze IA."

The comparison between Chocolate-on-White material from Tell Abu al-Kharaz and Pella reveals many common features: all six types are represented at both sites, the bichrome decoration is rare, and many of the decorative elements, such as the pendant triangles, framed dots, framed wavy lines and framed running rhombs, are represented in the material from both sites. The suggested chronological framework for the Tell Abu al-Kharaz Chocolate-on-White material may therefore also be applied to the dating of the Pella material: that is the later part of the Middle Bronze Age and the early part of the Late Bronze Age, or more precisely Middle Bronze Age IIC-Late Bronze Age IA with an outcrop into the Late Bronze Age IB for the Chocolate-on-White III Ware.

Other wares from Tomb 62 are a Cypriote Proto Base-ring bowl ${ }^{24}$ with a wishbone handle, a Cypriote spindle bottle of Red Lustrous Wheel-made Ware and 12 (Cypriote?) Black Lustrous Wheel-made spherical juglets. The present excavations of the author at Tell el-cAjjul have produced contexts, in which Black and Red Lustrous Wheel-made were found (FISCHER 2003: 264, table 1; for the Cypriote material compare with the charts in ÅsTRöm 1972: 700-701). The earliest Black Lustrous Wheel-made so far derives fron Horizon 6 (1 sherd), and thereafter in Horizon 5 ( 4 sherds). The preliminary date of Horizon 6 is the end of the Middle Bronze Age/ late Second Intermediate Period.

Finds which in addition to the pottery may contribute to the discussion of the "post quem" date of

23 Cf. also S. Bourke (pers. communication) who suggests a "horizontal" stratigraphy and not a vertical.

24 ERIKSSON (forthcoming) has reclassified this bowl as Proto Base-ring; contra PotTs (1992: 71 and pl. 58:4)

who classified this bowl as Monochrome. The diverging classifications do not influence the chronology of the tomb because both wares exist side by side from Late Cypriote IA(1)2 to IB1 (А̊ström 1972: 700). 
the tomb are the 56 scarab seals (Роттs 1992: 78-79; 55 are discussed in RICHARDS 1992). RICHARDS suggests a primary association of the Pella corpus with Tell el-cAjjul and a cultural relationship between Pella and Tell el-cAjjul. Richards (1992: 43) dates the scarabs to the Middle Bronze Age IIB/C, corresponding to the $15^{\text {th }} / 17^{\text {th }}$ Dynasties of the Second Intermediate Period in Egypt. The iconography of three of the scarabs shows royal names. One is Auserre Apophis ${ }^{25}$ whose name is identified with some certainty. Auserre Apophis, who ruled contemporaneously with Kamose $^{26}$ and was also involved in battles with him (НАBACHI 1972). Auserre Apophis lies either in fourth position within the sequence of the Hyksos kings at Avaris (HELCK 1962: 133) or in fifth position (VON BECKERATH 1964: 127). The second scarab probably shows the name of Nubuserre, who is one of the less important rulers of the $15^{\text {th }}$ Dynasty (WARD 1984: 163) or the $16^{\text {th }}$ Dynasty (VON BeCKerath 1964: 139). The third, which is quite unusual, may possibly show the name of Khamose, a ruler of the $17^{\text {th }}$ Dynasty. All the scarabs have parallels at Tell el-cAjjul (KeEL 1997: 106-525 passim) and it is not unlikely that they were produced in southern Palestine, maybe at Tell el${ }^{\mathrm{c} A j j u l}$ itself.

\section{Conclusions}

The investigation of the vast Pella material offers the opportunity to study complete vessel shapes and to refine the criteria which were established in accordance with the observation of the Tell Abu al-Kharaz material. It has once more been confirmed by the excellent finish and the high artistic level of the Pella Chocolate-on-White vessels that this ware represents a peak in the pottery production of Canaanite potters. It is therefore surprising to find almost no parallels beyond the southern Levant, the reason for which is either the competition from the dominating Cypriote producers and their main trading partners very likely at Tell el-cAjjul, ${ }^{27}$ or possibly too a high price level or a matter of taste and demands. It also seems that the Chocolate-on-White vessels from Pella are more uniform in appearance than the Tell Abu

25 Approximately $1585-1542$ B.C. according to BIETAK (1994: 58) who uses the Low Chronology.

26 Approximately 1543-1539 B.C. according to BIETAK.

27 The site which produced by far the most of the Cypriote ceramic exports during the Middle and Late Bronze Age anywhere outside Cyprus is Tell el- ${ }^{\mathrm{C}} \mathrm{Ajjul}$ (FISCHER in press).
al-Kharaz material, which may point to a small number of potters from a few, or maybe just one, centre(s) of production. In contrast, Tell Abu al-Kharaz shows a diversity, which is also reflected by petrography, which points to an import from different workshops. However, there is one Chocolate-on-White II jug from Tell Abu al-Kharaz, which seems to have been manufactured from local clay. ${ }^{28}$ Petrography, which is certainly the most suitable technique for exploring the relationship of the Chocolate-onWhite material from these two sites, should be utilized as a future project on the Pella material as well.

The seven radiocarbon dates of relevant contexts at Tell Abu al-Kharaz confirm the provisional chronological framework of the author which earlier was based merely on parallels. A general observation is that the Oxford (OxA) dates of Chocolateon-White II cover a wider time span compared with the Vienna (VERA) dates which provide better statistics. The two $2 \sigma$ dates from Oxford cover a period from 1672 B.C. to 1394 B.C. which would satisfy the supporters of all chronologies - High, Middle or Low (cf. А̊ström ed. 1987; Bietak ed. 1992) -, whereas four of the five Vienna dates ${ }^{29}$ would lend more support to a relative low chronology of the first half of the Late Bronze Age with their $2 \sigma$ dates covering a period from 1520 B.C. to 1410 B.C. (and overlapping the Oxford dates).

\section{Acknowledgements}

The investigation was only possible due to the kind permission and support of Dr. S.J. Bourke, the present director of the University of Sydney excavations at Pella (Tabaqat Fahl), and Professor em. J.B. Hennessy, the former director of the excavations. I am very grateful to them. Valuable help has also been received from P. Donnelly, MA, who kindly provided the drawings from Pella Tomb 62, and from Dr. K.N. Sowada, the curator of the Nicholson Museum. The study of the Chocolate-on-White Wares at Pella is the topic of Mr. Donnelly's thesis. I am therefore very much obliged to Mr. Donnelly for fruitful discussion of our common research interests. Financial support for the visit to Sydney and

\footnotetext{
28 There is a find of a potter's wheel of basalt from Phase V, i.e. LB IA at Tell Abu al-Kharaz.

29 The sample from a context with questionable Chocolate-on-White II is here excluded.
} 
the study period has gratefully been received from the following sources: the SCIEM2000 project, the Royal Academy of Letters, History and Antiquities, Stockholm, and the Australian Academy of the Humanities, Canberra. I am much indebted to Professor W. Kutschera, the head of the Institute for Radium Research and Nuclear Physics, University of Vienna, and his VERA (Vienna Environmental
Research Accelerator) team, and to Dr. P. Stadler from the Museum of Natural History, Vienna, who all processed and dated the samples from Tell Abu al-Kharaz immediately. I would also like to thank D. Melman, MA, for her valuable assistance, and last but not least Professor M. Bietak, who has supported this project and accepted this study for publication in Egypt and the Levant.
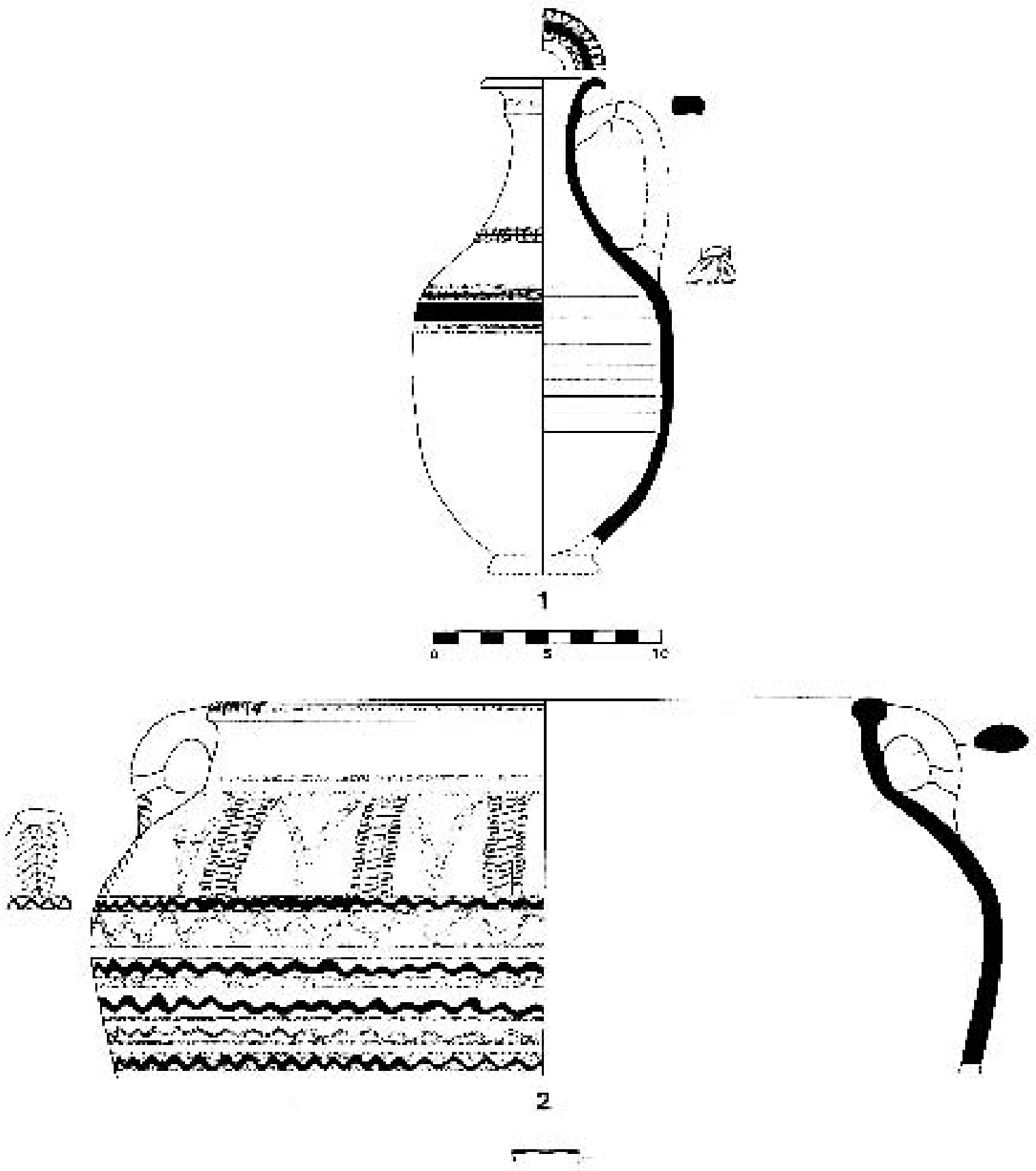

Fig. 2 Chocolate-on-White from Tell Abu al-Kharaz.

1. Proto-Chocolate-on-White Bichrome. / 2. Chocolate-on-White Bichrome 

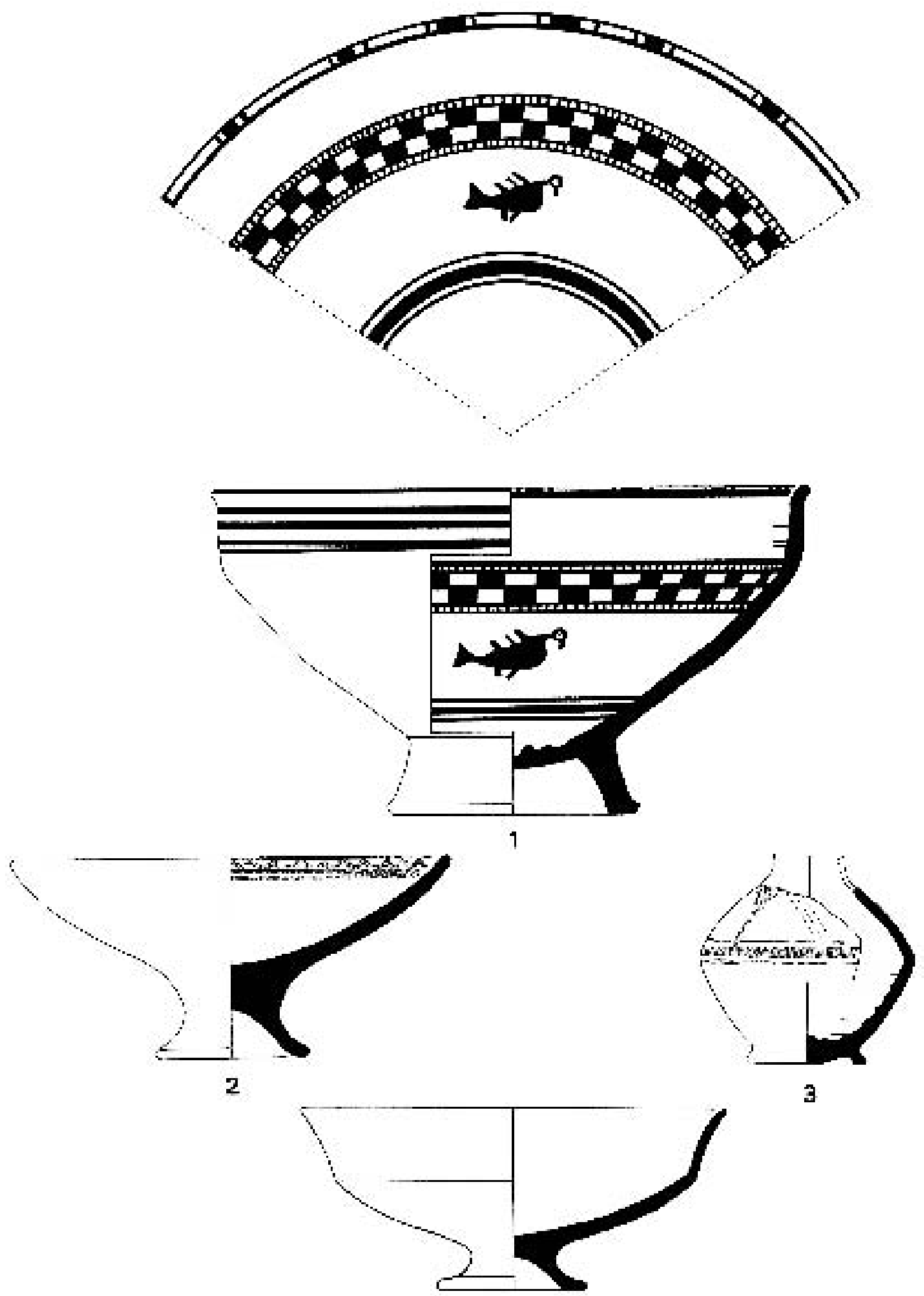

4

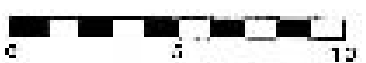

Fig. 3 Chocolate-on-White from Tell Abu al-Kharaz.

1.-3. Chocolate-on-White I. / 4. Eggshell Ware 

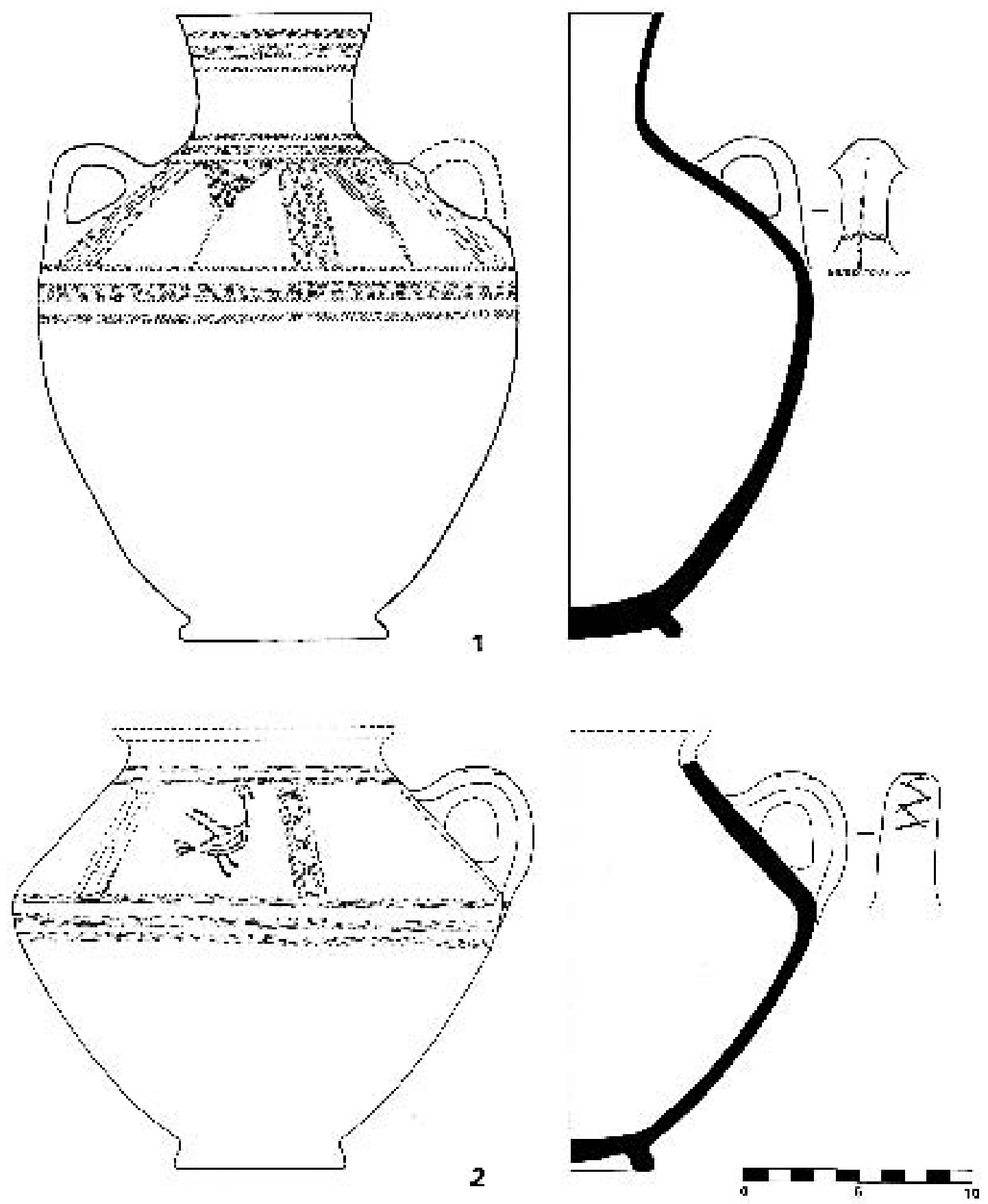

Fig. 4 Chocolate-on-White from Tell Abu al-Kharaz.

1. Transitional Chocolate-on-White I/II. / 2. Chocolate-on-White II 

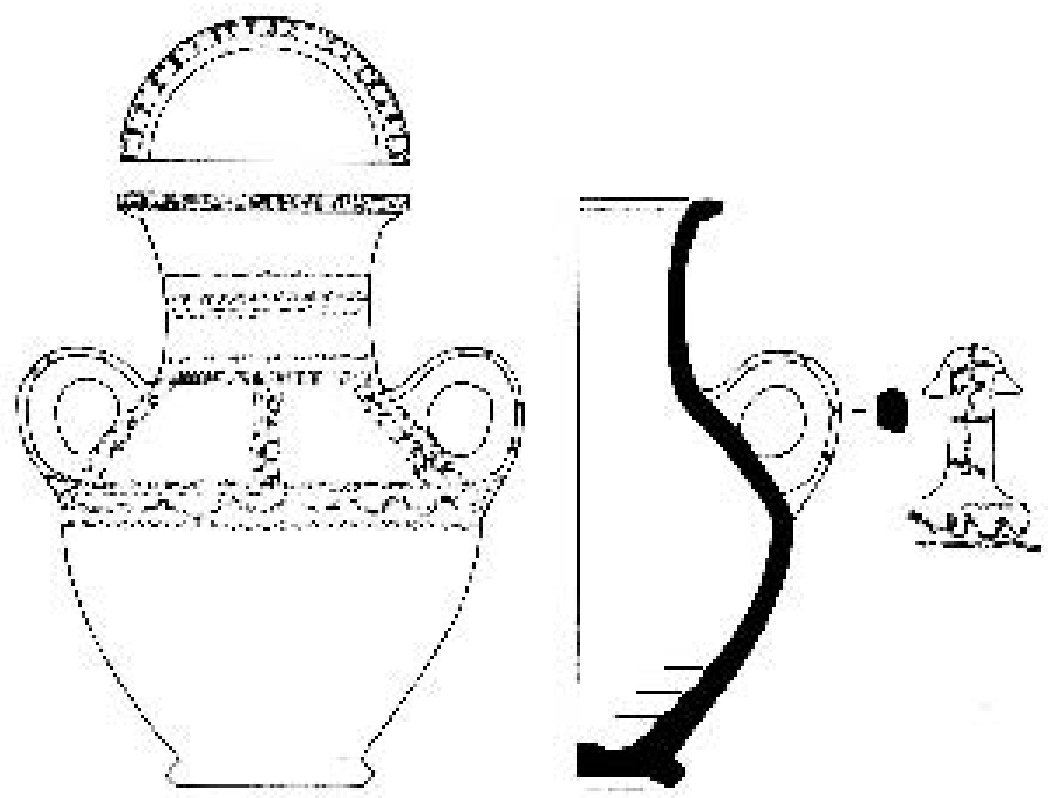

1

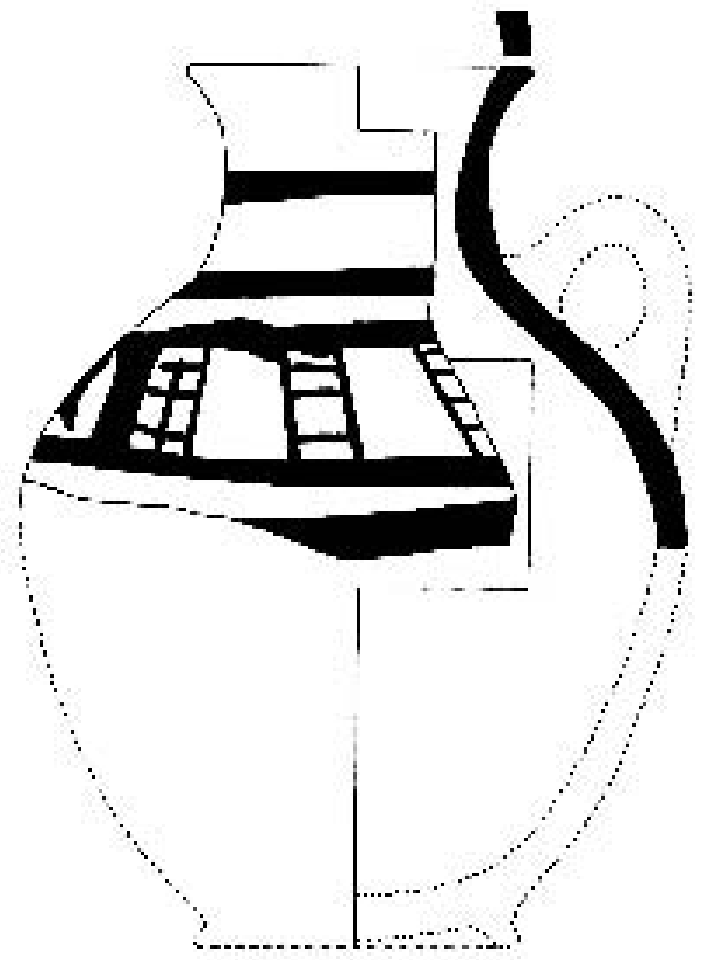

2

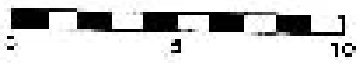

Fig. 5 Chocolate-on-White from Tell Abu al-Kharaz. 1. Chocolate-on-White II. / 2. Chocolate-on-White III 

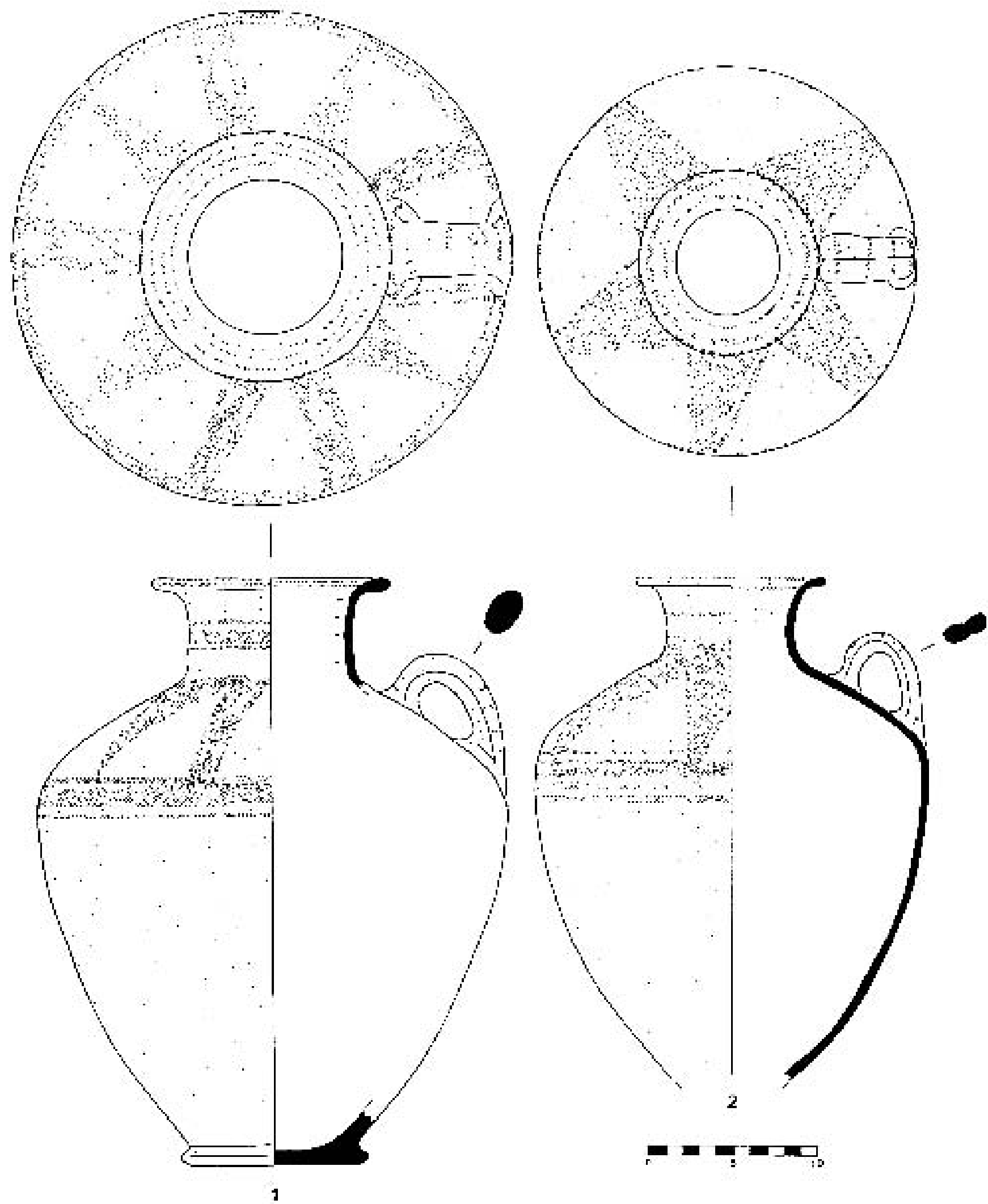

Fig. 6 Chocolate-on-White from Pella Tomb 62. 1, 2 Jugs Type I1 

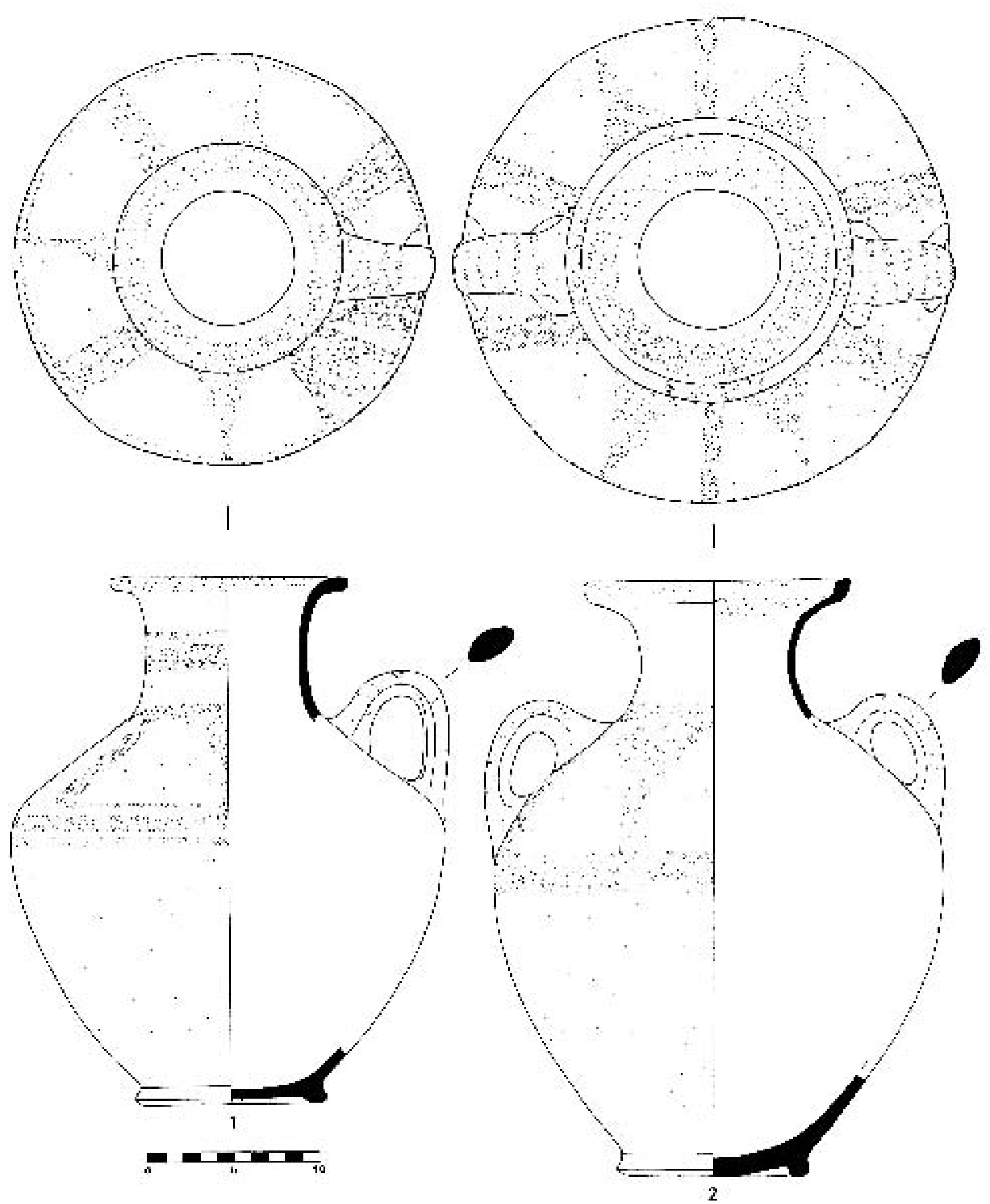

Fig. 7 Chocolate-on-White from Pella Tomb 62. 1. Jug Type III1. / 2. Jug Type III2 


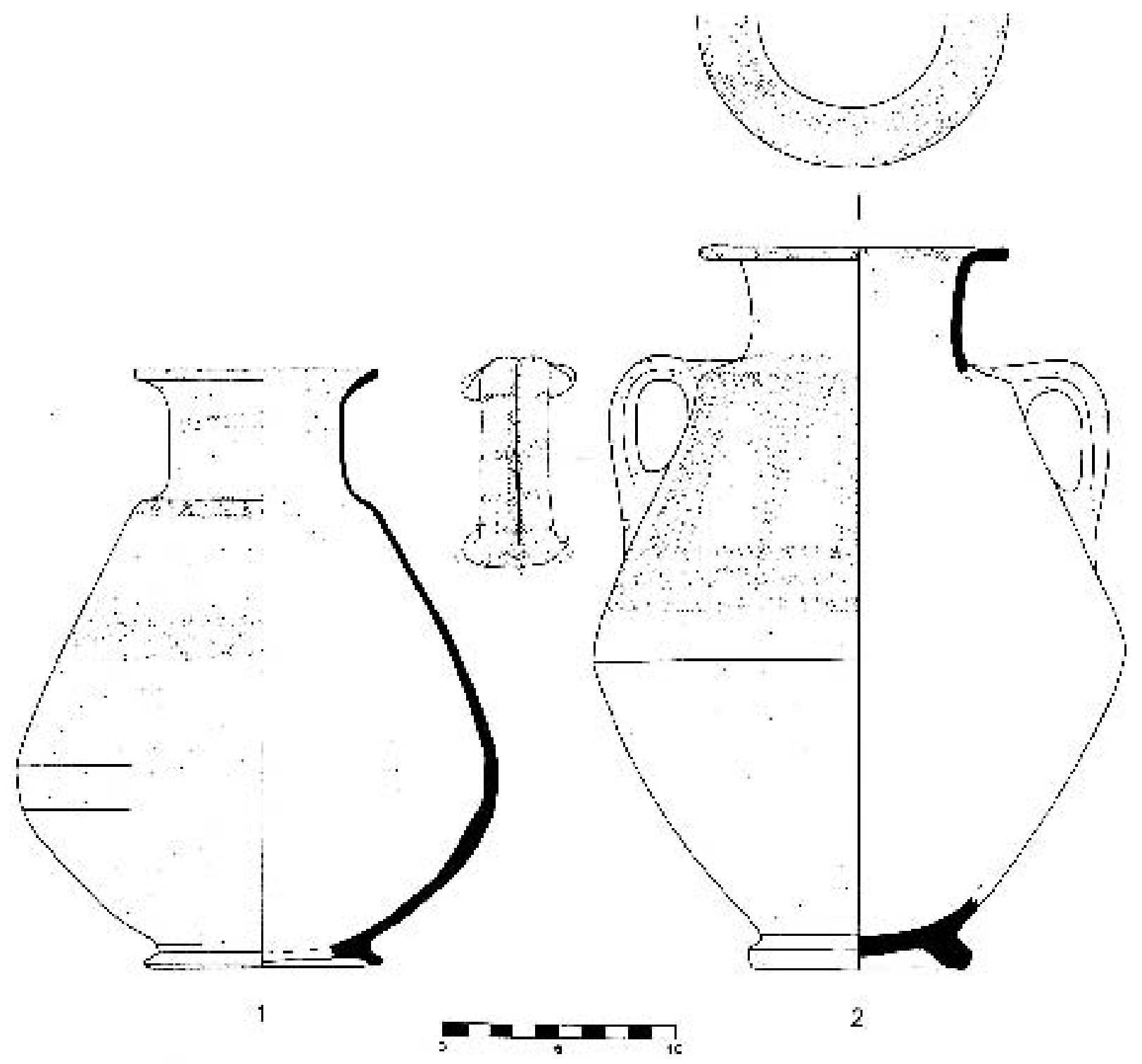

Fig. 8 Chocolate-on-White from Pella Tomb 62. 1. Jug Type IV0. / 2. Jug Type IV2 


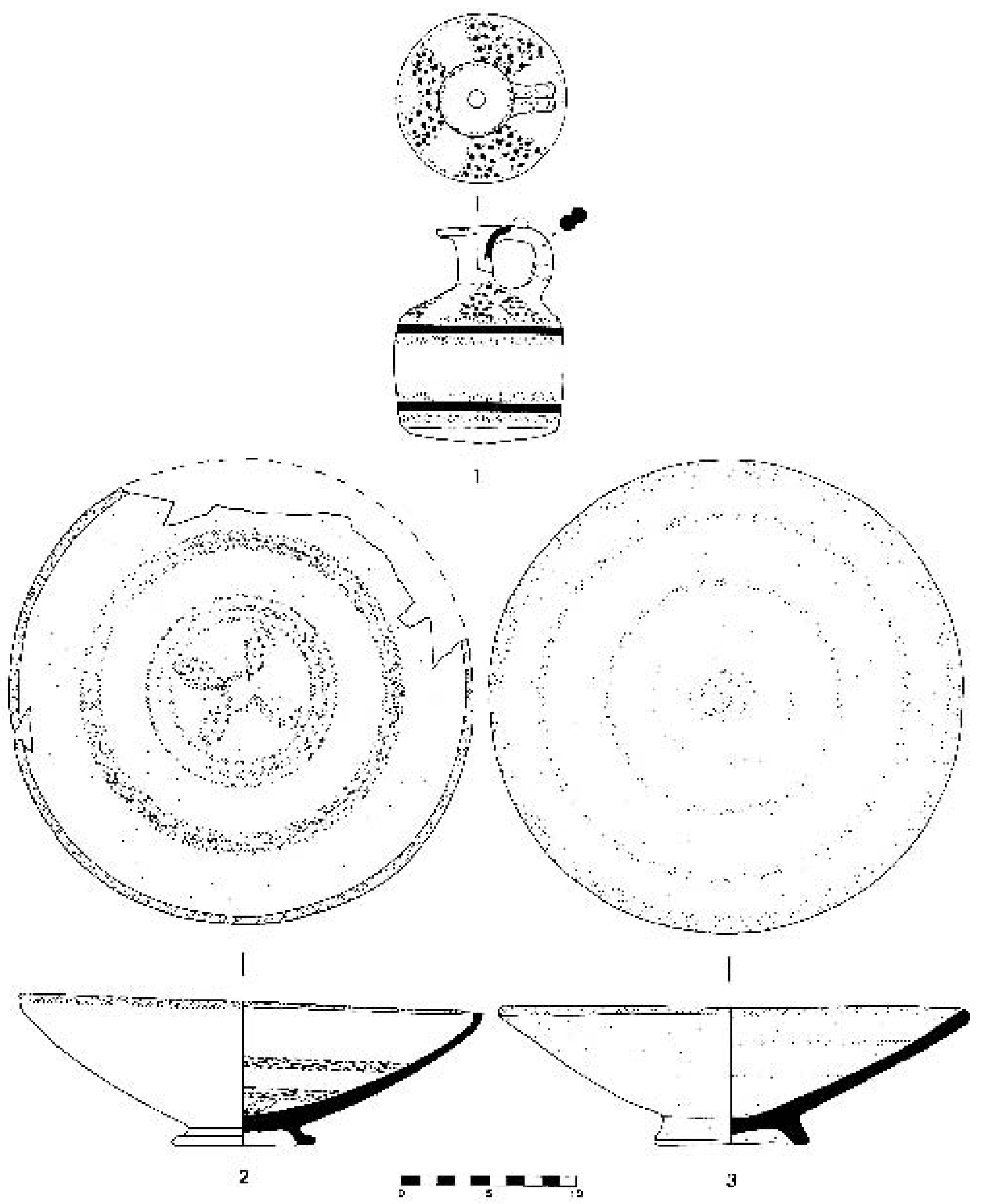

Fig. 9 Chocolate-on-White from Pella Tomb 62. 1. Cylindrical juglet. / 2, 3. Large shallow bowls 


\section{Bibliography}

AMIRAN, R.

1970 Ancient Pottery of the Holy Land, New York 1970.

Åström, P. (ed.)

1987 High, Middle or Low? Acts of an International Colloquium on Absolute Chronology Held at the University of Gothenburg 20th-22nd August 1987, Göteborg 1987.

ÅsTrÖM, P.

1972 The Swedish Cyprus Expedition IV: 1D, Lund 1972.

BECKERATH, J. VON

1964 Untersuchungen zur politischen Geschichte der zweiten Zwischenzeit in Ägypten, Glückstadt 1964.

BIETAK, M. (ed.)

1992 High, Middle or Low? Acts of the Second International Colloquium on Absolute Chronology. The Bronze Age in the Eastern Mediterranean, Egypt and the Levant 3, Vienna 1992.

1994 Pharaonen und Fremde. Dynastien im Dunkel. Catalogue: 222. Ausstellungskatalog, Historisches Museum der Stadt Wien, Wien 1994.

BOURKE, S.J.

1994 Preliminary Report on the University of Sydney's Fourteenth Season of Excavations at Pella (Tabaqat Fahl), in: BOURke, S.J., SPARKs, R.T., SOWADA, K.N., and MaIrs, L.D (same title), ADAJ 38 (1994), 81-126.

ERIKSSON, K.

forthc. Historical transitions Revealed in Tomb 62 Some Historical Implications of the Late Cypriote Pottery in the Middle/Late Bronze Age at Pella in Jordan, in: A.G. Walmsley (ed.), Fifty Years of Australian Archaeology in Jordan.

FISCHER, P. M.

1997 A Late Bronze to Early Iron Age Tomb at Sahem, Jordan. Abhandlungen des Deutschen Palästina-Vereins 21, Wiesbaden 1997.

1998 Tell Abu al-Kharaz. The Swedish Jordan Expedition 1997. Eight Season Preliminary Excavation Report, ADAJ42 (1998), 213-223.

1999 Chocolate-on-White Ware: Typology, Chronology and Provenance. The Evidence from Tell Abu alKharaz, Jordan Valley, BASOR 313 (1999), 1-29.

2000a The Early Bronze Age at Tell Abu al-Kharaz, Jordan Valley: A Study of Pottery Typology and Provenance, Radiocarbon Dates, and Synchronism of Palestine and Egypt During Dynasty 0-2, 201-232, in: G. PHILIP and D. BAIRD (eds.), Ceramic and Change in the Early Bronze Age of the Southern Levant, Sheffield 2000

2000b The Jordan Valley and Cyprus: Chocolate-onWhite and White Slip Wares, 51-58, in: P. ÅsTröm and D. Sürenhagen (eds.), Periplus. Festschrift für Hans-Günther Buchholz zu seinem achtzigsten Geburtstag am 24. Dezember 1999, Studies in Mediterranean Archaeology 127, Göteborg 2000.

2003 The Preliminary Chronology of Tell el-cAjjul: Results of the Renewed Excavations in 1999 and
2000, 263-294, in: M. BIETAK (ed.) The Synchronisation of Civilisations in the Eastern Mediterranean in the Second Millennium BC. II: Proceedings of the SCIEM 2000 - EuroConference, Haindorf, 2nd of May-7th of May 2001, CChEM 4, Vienna.

FISCHER, P.M., and SADEQ, M.

2000 Tell el-cAjjul 1999. A Joint Palestinian-Swedish Field Project: First Season Preliminary Report, EE⿱乛⿻ 10 (2000), 211-226.

2002 Tell el-cAjjul 2000. Second Season Preliminary

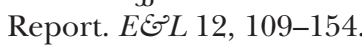

Goren, Y., and Fischer, P.M.

1999 Petrographic Study of Ceramic Assemblages as a Regional Project: The Early and the Late Bronze Ages in the Central Jordan Valley, 143-146, in: S. PIKE and S. GiTIN (eds.), The Practical Impact of Science on the Near Eastern and Aegean Archaeology, Wiener Laboratory Monograph 3. American School of Classical Studies, Athens 1999.

HABACHI, L.

1972 The Second Stele of Kamose and his Struggle against the Hyksos Ruler and his Capital. ADAIK 8, Glückstadt 1972.

HELCK, W.

1962 Die Beziehungen Ägyptens zu Vorderasien im 3. und 2. Jahrtausend v. Chr., Wiesbaden 1962.

HenNessy, J. B.

1985 Chocolate-on-White Ware at Pella, 100-113, in: J. N. TubB (ed.), Palestine in the Bronze and Iron Ages. Papers in Honour of Olga Tufnell, London 1985.

KEEL, O.

1997 Corpus der Stempelsiegel-Amulette aus Palästina/Israel. Von den Anfängen bis zur Perserzeit. Katalog Band 1: Von Tell Abu Farag bis ${ }^{C}$ Atlit. OBO 3. Series Archaeologica, Freiburg 1997.

KNAPP, A.B.

1993 Society and Polity at Bronze Age Pella: An Annales Perspective, Sheffield 1993.

McNicoll, A., Smith, R., and Hennessy, B.

1982 Pella in Jordan 1, Canberra 1982.

PotTs, T.F

1985 Area XI, 205-208, in: Potts, T.F., Colledge, S.M., and EDWARDS, P.C., Preliminary Report on a Sixth Season of Excavation by the University of Sydney at Pella in Jordan (1983/84). ADAJ 29 (1985), 181-210.

1992 Part II: The Tombs, 35-81, in: SмITH, R.H., and Potтs, T.F.: The Middle and Late Bronze Ages, in: Nicoll, A. W., Edwards, P. C., Hanbury-Tenison, J., Hennessy, J. B., Potts, T. F., Smith, R. H., WalmSLEY, A., and Watson, P., Pella in Jordan 2. Mediterranean Archaeology Supplement 2: Sydney 1992.

RICHARDS, F.V.

1992 Scarab Seals from a Middle to Late Bronze Age Tomb at Pella in Jordan. OBO 117, Freiburg 1992. 
VAughan, S.J.

1999 Contributions of Petrography to the Study of Archaeological Ceramics and Man-made Building Materials in the Aegean and Eastern Mediterranean, 117-125, in: S. PIKE and S. GiTIN (eds.), The Practical Impact of Science on the Near Eastern and Aegean Archaeology, Wiener Laboratory Monograph 3. American School of Classical Studies, Athens 1999.

WARD, W.

1984 Royal-Name Scarabs, in: O. Tufnell, Studies on Scarab Seals, Vol. II. Scarab Seals and their Contribution to History in the Early Second Millennium BC, Warminster 1984.
Wentworth, C. K.

1922 A Scale of Grade and Class Terms for Clastic Sediments, Journal of Geology 30 (1922), 377-392.

1933 Fundamental Limits to the Sizes of Clastic Grains, Science 77 (1933), 633-634. 